\title{
Teacher Cognition and Grammar Teaching in the Saudi Arabian Context
}

\author{
Iftikhar Ahmad $^{1}$ \\ ${ }^{1}$ Department of Humanities and Administrative Sciences, Unaizah Community College, Qassim University, \\ Saudi Arabia \\ Correspondence: Iftikhar Ahmad, Department of Humanities and Administrative Sciences, Unaizah Community \\ College, 4394, Unaizah, Qassim University, Saudi Arabia.
}

Received: September 25, 2018 Accepted: November 3, 2018 Online Published: November 8, 2018

doi: $10.5539 /$ elt.v11n12p45

URL: https://doi.org/10.5539/elt.v11n12p45

\begin{abstract}
While much has been written about teacher cognition in grammar teaching, research investigating non-native English as a Foreign Language (EFL) teacher cognition in grammar teaching remains limited. This study intends to investigate non-native EFL teacher cognition in teaching grammar to university students in the Saudi Arabian context. More specifically, the study examins the interplay between these teachers' beliefs and practices in grammar teaching across mother tongue and gender. For this purpose, the study used mixed methods design, and employed a five-point Lickert scale questionnaire triangulated by a structured classroom observations checklist. Sixty teachers were selected for questionnaire, based on stratified random sampling; while eight teachers were observed multiple times. Teachers' selection for observations was based on purposive sampling. Both types of data were analysed statistically using Statistical Package for Social Sciences (SPSS). Descriptive analyses and independent-samples t-tests were employed. The results of independent samples t-tests indicated that there were no statistically significant differences in the beliefs of teachers across mother tongue and gender. The main finding of the study, revealed through descriptive analysis of the data, is that beliefs and practices of teachers across mother tongue and gender were at odds resulting into weak teacher cognition. The study suggests pedagogical implications for improved teacher cognition and hence, better grammar teaching in the Saudi Arabian context.
\end{abstract}

Keywords: beliefs, classroom practices, grammar teaching, teacher cognition

\section{Introduction}

Teacher cognition research is a relatively new phenomenon that has yet to be explored in the Saudi Arabian EFL context (Alghanmi \& Shukri, 2016). Research about EFL teacher cognition in general and grammar teacher cognition in particular is rare in the Saudi Arabian context (Aljohani, 2012; Assalahi, 2013); and consequently, there is no comprehensive picture to understand EFL teacher cognition in grammar teaching properly. Several studies have highlighted EFL teachers' outdated teaching methods and students' low proficiency level in English in Saudi Arabia (Al-Seghayer, 2011; Grami, 2010; Javid, Farooq, \& Gulzar, 2012), specifically grammar (Chowdhury, 2014; Khan, 2011); however, no research has attempted to investigate EFL teacher cognition, and hence there is a gap in research in the Saudi Arabian context regarding EFL teacher cognition in grammar teaching. Moreover, mainstream educational research presents little or no evidence regarding the interplay between non-native EFL teachers' beliefs and practices in grammar teaching.

Borg (1998) observes that empirical research has proved that teachers' classroom practices are determined by their beliefs. However, he feels that teachers' pedagogical belief system is still relatively unexplored. Borg (2009) argues that the primary concern of teacher cognition research lies with the unobservable dimension of teaching, teachers' mental lives, which play a pivotal role in their instructional choices. Summarizing the relationships between teachers' pedagogical beliefs and their classroom practices, Borg (2009) is of the view that they do not only act as a filter through which teachers interpret new information and experience but they also exert a persistent long-term influence on teachers' instructional practices. Borg (2003) realizes that to better understand teaching it is imperative to understand teachers' thoughts and beliefs that influence what teachers practice in the classroom. In line with Borg, Pajares (1992) also maintains that teachers' beliefs influence their judgments and in turn their classroom practices. Therefore, it is imperative to get profound knowledge of 
teachers' beliefs, without which it will not only be difficult to fully understand the complexity involve in the teaching and learning process, but also how they impact teachers' classroom practices (Assalahi, 2013).

Moreover, in language teacher cognition research, much effort has been paid on studying the cognition of pre-service teachers or ESL teachers and little is known regarding the cognition of EFL in-service teachers in international contexts where languages are taught by non-native teachers (Canh, 2011; Mohamed, 2009). Furthermore, most of the teacher cognition studies in grammar teaching have been conducted with native speaking English language teachers (Borg, 2009); and, almost all the studies in the literature that aimed to explore language teacher cognition in grammar teaching were conducted in ESL settings as compare to EFL contexts (Borg, 2003; Gilje, 2011). The present study is a step in that direction to fill this gap and investigate EFL teacher cognition in teaching grammar to university students in Saudi Arabia.

Furthermore, the choice of grammar teaching for this study is based on the anecdotal evidence that EFL students find this aspect of language the most difficult (Al-Mekhlafi \& Nagaratnam, 2011; Shiu, 2011). Additionally, knowledge of grammar is mostly responsible for students' positive performance in language production (Borg, 2013). At the same time, it also influences other areas of language teaching and learning, and thus facilitates students' understanding of the language (Borg, 1999). Furthermore, a sound knowledge of grammar ensures proficiency and accuracy in target language, which highlights grammar as an important element in language teaching and learning (Batstone \& Ellis, 2009).

Hence, the English language teacher cognition in Saudi Arabia requires evaluation so as to bring improvement in its educational system. The study is designed to investigate EFL teacher cognition with respect to grammar teaching to university students. It is envisaged that the study would be helpful to EFL teachers in Saudi Arabia by inviting them to reflect on their beliefs and practices for a better grammar teaching and learning process.

The field of teacher cognition entails investigating teachers' pedagogical beliefs about language teaching and learning, which in turn interprets teachers' actual classroom practices more effectively (Aljohani, 2012). It is generally accepted that teachers' classroom practices are rooted in their pedagogical beliefs and that beliefs affect and guide teachers' decision making (Phipps \& Borg, 2009). This relationship is perceived to be interactive and ongoing. Beliefs drive practices; however, experiences and reflection on practices may lead to changes in beliefs (Sato \& Kleinsasser, 2004). Canh (2011) also lends support to this opinion and maintains that beliefs and practices are mutually informing, with beliefs informing practices and practices further informing beliefs.

Thus, this study investigates the extent to which the interplay between EFL teachers' beliefs and practices shape their cognition in teaching grammar to university students in the Saudi Arabian context. More specifically, the study intends to investigate the interplay between non-native EFL teachers' beliefs and practices in grammar teaching across mother tongue and gender. EFL teachers in the Saudi Arabian context fall into three camps: native English speaking EFL teachers, native Arabic speaking EFL teachers, and EFL teachers from other Asian countries (Khan, 2011). These teachers teach English grammar to under graduate students, aged 18-21, for two years. Non-native EFL teachers are the specific focus of this study. With this aim, the study intends to investigate answers to the following questions:

1). To what extent does the interplay between non-native Arab and non-Arab EFL teachers' beliefs and practices shape their cognition in teaching grammar to university students in Saudi Arabia?

2). To what extent does the interplay between non-native male and female EFL teachers' beliefs and practices shape their cognition in teaching grammar to university students in Saudi Arabia?

\section{Literature Review}

\subsection{Teacher Cognition Research}

Researchers in the field of teacher cognition have used variety of terms to explain this phenomenon. Main stream educational literature is replete with diverse terminologies. In teacher cognition studies, researchers have used similar terms for different concepts and different terms for similar notions. A prominent example is that of Simon Borg, who used 'personal pedagogical systems' (Borg, 1998, p. 9), 'teachers' theories' (Borg, 1999, p. 157), and 'teacher cognition' (Borg, 2003, p. 96) to refer to L2 teachers' beliefs. Gabillon (2013) observes that since 2004, five terms are most commonly used in teacher cognition research. They are: teacher beliefs, teacher cognitions, teacher perceptions, pedagogical beliefs and teacher thinking. In the present study, the term 'teacher cognition' is used as an umbrella term for all the concepts. Borg (2003) defines teacher cognition as "what teachers think, know, and believe and the relationships of these mental constructs to what teachers do in the language teaching classroom" (p. 81). This definition indicates that teachers have cognitions about all aspects of their work. 
Researchers have relatively recently started to recognize the importance of investigating the various dimensions of teacher cognition and its impact on teaching (Mohamed, 2006). Research on language teacher cognition began to emerge in 1990s, which got momentum in the later years and continues to do so. This trend generated a substantial body of research which led Borg (2003) claim 1990-2000 as the decade of change in research on teacher cognition.

According to Gabillon (2013, p. 6), research on teacher cognition can be divided into five main groups. These are: 1) research on the relationship between teachers' beliefs and their classroom practices; 2) research on teachers' beliefs as a source for teacher awareness and professional growth; 3) research on teachers' beliefs about educational innovation; 4) research on the nature of teacher beliefs; and, 5) research on discrepancies between teachers' and learners' beliefs.

These five categories indicate that various dimensions of teacher cognition are investigated; however, the field of teacher cognition research is not free from potential challenges. Researchers have categorically stated numerous challenges faced by teacher cognition research. Gilje (2011) reports some of the most common challenges. They are: 1) most of the research on teacher cognition is about L1 settings; 2) most of the research on teacher cognition in other languages is about ESL as opposed to EFL; 3) the target language is mostly English; 4) longitudinal research is very rare; and, 5) multiplicity of terminology as opposed to a common terminology. In a similar vein, Mohamed (2006) also reports the limitations in research on language teacher cognition. She observes that most of the studies regarding teacher cognition are about native speaking teachers in developed countries, while most of the English language teachers are non-native speakers. Therefore, she claims that the present day research regarding teacher cognition does not totally represent most of the language teaching and learning contexts. In view of this gap in research on language teacher cognition, the present study tries to address this gap by investigating non-native EFL teacher cognition in teaching grammar to university students in the Saudi Arabian context.

\subsection{Teacher Cognition in Grammar Teaching}

To date, few empirical studies have attempted to investigate the relationship between grammar teachers' beliefs and classroom practices (Borg, 2003); and those that have been conducted largely agree that these relationships are very complex (Mohamed, 2006); as teachers' classroom practices may not necessarily manifest their beliefs about grammar teaching; which may be influenced by several contextual factors (Nishimuro \& Borg, 2013). For example, in Nishimuro and Borg's (2013) study, teachers were following explicit grammar instruction, underpinned by the belief that this approach is vital to EFL paradigm. Teachers believed in the utility of communicative activities; however, their grammar lessons were teacher-centered and without such activities. These teachers believed contextual factors, such as lack of time, mostly responsible for absence of communicative activities. Yet, another factor reported by the researchers underlying teacher cognition was the teachers' own language learning histories. These teachers' grammar teaching practices reflected the way they were taught in schools.

More recent studies examining the relationships between grammar teachers' beliefs and classroom practices have reported contradictory results. For instance, Kalsoom and Akhtar's (2013) study reveals that teachers were greatly in favour of explicit grammar teaching and taught grammar deductively. On the contrary, Aljohani (2012) reports that teachers believed that both form and meaning should be focused and that grammar should be taught in meaningful context. Moreover, they believed that knowledge of grammar leads to accuracy in language. However, these teachers believed that inductive approach of grammar teaching was better than deductive approach. Similarly, Chowdhury's (2014) findings also lend support to the claim that EFL grammar teachers mostly apply inductive approach to teach English grammar. However, there are dissenters to this view. According to Al-Naeem's (2007) findings, English language teachers teach grammar lessons deductively. These contrasting results reveal that only one approach is not in vogue among EFL teachers, and they employ different approaches to teach English grammar. These different grammar teaching approaches are rooted in teachers' pedagogical beliefs.

Teachers' classroom practices do not always reflect their beliefs about grammar teaching. There are empirical evidences which show mismatches between teachers' beliefs and practices in grammar teaching. For example, Phipps and Borg (2009) reported that beliefs and practices of grammar teachers were at odds with one another. The factors considered responsible for such inconsistencies were contextual and personal factors, like learners' motivation and expectations, curriculum, classroom management, examinations and time constraints. The inconsistencies between teachers' beliefs and practices in grammar teaching have also been reported by Hos and Kekec (2014). Their study showed a range of mismatches, such as, mismatches in error correction, place of grammar in language teaching, teaching methodology, inductive/deductive teaching, the use of L1 and the 
contextual teaching of grammar. The researchers reported that several environmental, social and psychological factors were responsible for such mismatches, due to which teachers were not able to apply their beliefs in classroom practices.

The success and failure of teaching and learning the target language is the outcome of the interplay between teachers' beliefs and practices. Beliefs determine classroom practices, and classroom experiences in turn shape, modify and form beliefs (Alnaqeeb, 2012). Hence, teachers' beliefs and practices interact bi-directionally, that is, beliefs influence practices but practices can also lead to changes in beliefs (Borg, 2009). Since individual teacher's beliefs are different (Kalsoom \& Akhtar, 2013), therefore, teaching styles are also different. Teaching styles reflect what works inside teachers' mind. Teachers' instructions in grammar are governed by what they believe and hence, teachers' decision-making is filtered by these beliefs (Borg, 2013; Pajares, 1992). Belief is one of the key factors in planning and delivering classroom instructions, including choice of syllabus, teaching methodology, teaching strategies, classroom management, and type of resources (Utami, 2016).

Borg (2009) states that the relationships between teachers' beliefs and actions are very crucial, as teachers' mental lives play a key role in their instructional choices. He argues that the questions to be addressed now is not simply 'what do teachers do?' but also 'what do they think?', 'what decisions do they make?' and 'why?' In other words, teachers cannot mechanically implement the curricula designed by others. They are thinking decision-makers, who make decisions before and while teaching.

Moreover, students' proficiency in the target language is directly influenced by the interplay between teachers' beliefs and classroom practices (Utami, 2016). Since teachers' beliefs act as mediators between the objectives of the curriculum and their implementation, therefore, if teachers' beliefs do not match those objectives, then it is likely that resistance will be generated resulting in low proficiency level of students (Canh, 2011). In effect, the low degree of success in many educational reforms has been seen as a major reason why the interplay between EFL teachers' beliefs and practices need to be investigated.

\section{Methodology}

This study followed mixed methods design to answer the research questions. This approach was considered helpful in analyzing the various beliefs and practices of EFL teachers with respect to their grammar teaching. Dörnyei (2007) acknowledges that the combination of methods has gained popularity over the last 15 years and "in social research it became synonymous with combining data sources to study the same social phenomenon" (p. 43). The basic assumption in mixing methods is that it provides better understanding of the research problem and research questions (Creswell, 2012). Thus, the study has been methodologically triangulated (Denzin, 2012) by the use of a questionnaire and a classroom observations checklist.

\subsection{Respondents}

The population of this study comprised non-native EFL teachers teaching grammar at Qassim University, Saudi Arabia. To draw the desired sample from the population for the present study, stratified random sampling was applied for the questionnaire. Stratified random sampling was used for this study because non-native EFL teachers in Saudi Arabia belong to two groups: Arab and non-Arab teachers. They were further divided into two more groups: male and female. Thus, a total of 60 non-native EFL teachers were selected for questionnaire. The identified sub groups in the population were adequately represented in the sample, as shown in Table 1.

Table 1. Demographic data of teacher respondents for questionnaire

\begin{tabular}{llcc}
\hline Arab/non-Arab & Gender & No of Respondents & Total \\
\hline \multirow{2}{*}{ Arab } & male & 15 & 30 \\
& female & 15 & \\
\multirow{2}{*}{ Non-Arab } & male & 15 & 30 \\
& female & 15 & \\
\hline
\end{tabular}

While for classroom observations, purposive sampling was utilized to get profound insights into the practices of the respondent teachers. For sample size in qualitative research, Creswell (2012) and Dörnyei (2007) believe that the concept of saturation should be the guiding principle. In line with this suggestion, eight teachers were observed; however, each teacher was observed three times. This is in line with Fraenkel and Wallen (2003), who 
suggest multiple observations than single observation, as this will obtain better and reliable data. Thus, a total of 24 classroom observations were conducted, as detailed in Table 2.

Table 2. Demographic data of teacher respondents for classroom observations

\begin{tabular}{llcc}
\hline Arab/non-Arab & Gender & No of Participants & No of Observations \\
\hline \multirow{2}{*}{ Arab } & male & 2 & 6 \\
& female & 2 & 6 \\
\multirow{2}{*}{ Non-Arab } & male & 2 & 6 \\
& female & 2 & 6 \\
\hline
\end{tabular}

\subsection{Research Instruments and Procedures}

In order to answer the research questions holistically, this study utilized two data collection tools: a close-ended questionnaire and a narrow focus classroom observations checklist. Questionnaire is the most popular research instrument in social sciences because of its capability to gather large amount of data quickly in a systematic manner (Dörnyei, 2007). For the present study, a 13-item closed-ended questionnaire was used to investigate teachers' beliefs about grammar teaching, and was developed on the basis of the existing literature on teachers' beliefs about grammar teaching. Teachers were required to respond to the items on a five point Likert scale, ranging from strongly agree to strongly disagree. Teachers' beliefs were sought in two areas of grammar teaching: grammar teaching approaches and error correction in grammar teaching. The questionnaire was divided into two sections. Section one aimed to collect demographic data from teachers, while section two attempted to collect teachers' beliefs about grammar teaching.

In order to observe the actual classroom practices of EFL teachers, a structured classroom observation checklist was utilized; however, during observations, notes were also taken. Fraenkel and Wallen (2003) point out two kinds of classroom observations: broad focus and narrow focus observations. Broad focus observations concentrates on overall picture, and narrow focus observations on representative behaviour of what is happening in the classroom. The choice of either of the two depends on practical issues, research objectives, research questions and a host of other factors. Hence, the observer can either observe holistically what is happening in the classroom or prepare a checklist of activities and tick accordingly (Zohrabi, 2013). This study utilized narrow focus classroom observations having a checklist because, in line with the research questions, only representative behaviour of EFL teachers was intended to observe. Furthermore, male teachers were observed by the researcher and female teachers were observed by a female volunteer, because female teachers cannot be observed by male teachers in Saudi Arabia due to cultural barriers. The female volunteer was an EFL teacher in the same university. Thus, narrow focus structured classroom observation checklist was purposefully utilized in order to make the observations by the two observers reliable, as the use of structured observational guidelines makes the observation process more reliable and helps to focus on key events (Dörnyei, 2007; Griffee, 2012).

The classroom observations checklist consisted of two sections, a demographic section and a list of practices regarding grammar teaching, complementing the items in the questionnaire. The categories frequently, occasionally and never were used to observe the presence or absence and frequency of the relevant practice. The column comments was provided to note down any aspect relevant to the practice that were not mentioned in the checklist. Thus, it helped to overcome any flaw in the checklist. Each of the eight teachers was observed three times at three-week intervals. Each lesson lasted for 50 minutes. Thus, a total of 20 hours of observational data were collected for the study. Moreover, the role of the researcher during classroom observation was non-participant observer.

\subsection{Validity and Reliability of the Instruments}

Data collection instruments for any study must ensure the issues of validity and reliability (Creswell, 2012). In this study, the validity of the tools was determined in different ways. For instance, the internal validity was achieved by method triangulation (Denizen, 2012); while, face validity, construct validity and content validity were checked by other PhD holders. To ensure validity of the questionnaire, expert opinion was sought from three $\mathrm{PhD}$ holders. The questionnaire was revised according to their suggestions.

Moreover, the procedure of member-checking was also utilized to help improve the accuracy, credibility and validity of classroom observations checklist. Participants were sent a copy of the observation checklist 
afterwards, and invited to confirm it as an accurate record of their practices. The participants affirmed the accuracy of the qualitative data, and hence, the study met the credibility of the research. In qualitative research, Creswell (2012) suggests considering at least two validation strategies, specifically, member checking and triangulation. Both these validation strategies are used in this study.

The internal-consistency reliability of the questionnaire was checked by using Cronbach's alpha in SPSS version 21. The results showed that the questionnaire had a high degree of internal consistency. The Cronbach's alpha of the questionnaire was .783, which suggested that the items had high internal consistency (Hamid, 2017).

With reference to observations, Seliger and Shohamy (1989) assert that the use of checklist for classroom observations increases its reliability, because the use of checklist guides the observer in classroom observations. Moreover, the interrater reliability of the classroom observations checklist was conducted by the researcher and another PhD student. The two observations were administered in the same classroom. After calculating the results of the two observations, only one disagreement was recorded. The interrater reliability of the classroom observations was calculated using Cooper and Hedges's (1994) formula, as shown:

Agreement Rate $=$ Number of observations agreed upon*100/Total number of observations

$$
\text { Agreement Rate }=12 * 100 / 13=92 \%
$$

Furthermore, for observing female teachers, a separate interrater reliability of classroom observations checklist was conducted by the female volunteer and another female lecturer. The observations of these two observers were calculated using the Cooper and Hedges's (1994) formula. Both observers found only one disagreement in their respective observations.

\subsection{Data Analysis Procedures}

Questionnaire data were analysed descriptively and inferentially with the help of means, standard deviations and t-tests to know the differences between different groups of teachers. Also, data collected through narrow-focus structured classroom observations checklist were evaluated quantitatively using SPSS ver. 21. Although qualitative research aims to describe things in a non-numerical way, yet the "non-numerical data of qualitative research can be changed into numerical ones by way of classification and categorization" (Alnaqeeb, 2012, p. 98), because the predetermined categories can result in numbers that can be treated statistically and analysed (Hitchcock \& Hughes, 1995). Similarly, Dörnyei (2007) also acknowledges that classroom observational data collected through structured observational scheme can be analysed by means of statistical procedures. Quantitative evaluation of classroom observations data was carried out on the grounds that the study aimed to investigate the frequency and presence or absence of the relevant practices. However, notes taken during classroom observations were evaluated qualitatively. The results of classroom observations data were compared and contrasted with the results of the questionnaire to know the interplay between beliefs and practices of EFL teachers in grammar teaching.

\section{Findings and Discussion}

Data from the questionnaire were analysed at two stages. In the first stage, t-tests were calculated comparing the mean scores of Arab EFL teachers with those of non-Arab EFL teachers, and male EFL teachers with those of female EFL teachers, as shown in Table 3. The results of t-tests display that there were no statistically significant differences in the mean scores of non-native EFL teachers across mother tongue and gender.

Table 3. Results of independent samples t-tests across mother tongue and gender

\begin{tabular}{lllcc}
\hline & $\mathrm{t}$ & $\mathrm{df}$ & Sig (2-tailed) & mean difference \\
\hline Mother tongue & .804 & 58 & .425 & .082 \\
Gender & 1.162 & 58 & .250 & .117 \\
\hline
\end{tabular}

In the second stage of analysis, descriptive analyses of the data of the questionnaire were conducted comparing the mean scores of Arab and non-Arab, and male and female EFL teachers. Moreover, classroom observation data, in the form of frequencies, were given beside questionnaire data in the same tables to have a clear picture of teachers' beliefs and practices in grammar teaching approaches and error correction in grammar teaching. 
Table 4. Comparative analysis of Arab and non-Arab EFL teachers' beliefs and practices in grammar teaching approaches

\begin{tabular}{lcccccccccc}
\hline & \multicolumn{4}{c}{ Questionnaire } & \multicolumn{3}{c}{ Classroom Observartion } \\
\cline { 2 - 11 } & \multicolumn{3}{c}{ Arab } & \multicolumn{1}{c}{ Non-Arab } & Arab & \multicolumn{3}{c}{ Non-Arab } \\
\cline { 2 - 11 } & $\mathrm{M}$ & SD & $\mathrm{M}$ & $\mathrm{SD}$ & $\mathrm{F}$ & $\mathrm{O}$ & $\mathrm{N}$ & $\mathrm{F}$ & $\mathrm{O}$ & $\mathrm{N}$ \\
\hline PPP Approach & 2.26 & .86 & 2.03 & .88 & & 4 & & 2 & 2 & \\
Task-based teaching & 4.23 & .77 & 4.16 & .64 & & & 4 & & & 4 \\
Rule-driven Approach & 2.50 & 1.04 & 2.06 & .52 & 4 & & & 4 & & \\
Rule-discovery Approach & 4.13 & .57 & 4.20 & .55 & & & 4 & & & 4 \\
Focus on Forms & 2.33 & 1.02 & 2.36 & 1.27 & 4 & & & 4 & & \\
Focus on Function & 4.23 & .50 & 4.20 & .61 & & & 4 & & & 4 \\
Intensive grammar teaching & 3.80 & 1.09 & 3.50 & 1.19 & & & 4 & & & 4 \\
Use of teaching aids & 4.23 & .67 & 4.16 & .69 & & 4 & & & 4 & \\
\hline
\end{tabular}

$\mathrm{PPP}=$ Presentation, Practice and Production, $\mathrm{F}=$ Frequently, $\mathrm{O}=$ Occasionally, $\mathrm{N}=$ Never.

The results in Table 4 demonstrate that Arab and non-Arab EFL teachers have similarity of perceptions regarding grammar teaching approaches, although more Arab teachers, than non-Arab teachers, believe in rule-driven deductive approach. Overwhelming majority of both groups of teachers do not believe in the traditional PPP approach, rule-driven approach and focus on forms approach, and believe in the innovative task-based approach, rule-discovery approach and focus on function approach. Also, the results of classroom observations show that there were no differences in the practices of teachers across mother tongue, and almost all observed teachers practiced traditional approaches as compared to innovative approaches.

Moreover, comparative analysis of questionnaire and classroom observations data of Arab and non-Arab EFL teachers reveal that beliefs and practices of the two groups of teachers were at odds. The findings reveal that overwhelming majority of both groups of teachers believe in innovative student-centered approaches; however, inside the classrooms they are not able to translate their beliefs into practice, and thus the classrooms are more teacher-centered than student-centered. Table 4 also shows that only two non-Arab teachers practiced all the three stages of PPP approach, while two non-Arab and all the four Arab teachers were confined only to the first two stages of the methodology. They only presented the grammatical structures and students practiced grammatical structures through drills. They did not proceed to the production stage where students themselves produce language. The findings also reveal that majority of the teachers believe in intensive grammar teaching; however, they did not practice this approach. Regarding the use of teaching aids, teachers' beliefs and practices were consistent. However, there was occasional use of teaching aids by the teachers, and complete realization of their beliefs into practice was not observed, although projectors and computers were available to them.

The findings in Table 4 demonstrate that Arab and non-Arab EFL teachers' classroom practices in the Saudi Arabian context are more in line with traditional grammar teaching approaches. The probable reasons for these discrepancies may be the teachers' consideration of Saudi students' weak proficiency level in English grammar (Khan, 2011), large-size classes (Grami, 2010) or teachers' own history of language learning in traditional teaching contexts, which make them stick to the same traditional approaches. The finding of the study about PPP and task-based teaching matches that of Nishimuro and Borg's (2013) finding, where teachers taught grammar without communicative activities, contrary to their beliefs. Also, the result of the study is consistent with the previous study by Hos and Kekec (2014) who reported inconsistencies between teachers' beliefs and practices regarding inductive/deductive teaching of grammar. Moreover, the result of the study is similar to that of Uysal and Bardakci's (2014) where teachers practiced focus on forms approach under the conviction that mechanical drills and explicit grammar instruction were necessary for language acquisition. Similarly, regarding intensive grammar teaching, the concept of internalization is missing in the respondent teachers' practices, which is inconsistent with the claim held by Ellis (2006), who believes that grammar teaching entails intensive instruction which is based on the concept of practice makes perfect. Furthermore, the finding of the study about the use of teaching aids is inconsistent with the finding by Alghanmi and Shukri (2016), who reported that majority of the teachers did not use authentic material to teach grammar. 
Table 5. Comparative analysis of Arab and non-Arab EFL teachers' beliefs and practices in error correction in grammar teaching

\begin{tabular}{lcccccccccc}
\hline & \multicolumn{4}{c}{ Questionnaire } & \multicolumn{3}{c}{ Classroom Observartion } \\
\cline { 2 - 12 } & \multicolumn{3}{c}{ Arab } & \multicolumn{1}{c}{ Non-Arab } & & Arab & & \multicolumn{3}{c}{ Non-Arab } \\
\cline { 2 - 12 } & $\mathrm{M}$ & SD & M & SD & F & O & N & F & O & N \\
\hline Tolerate students' errors & 3.26 & 1.41 & 3.53 & 1.27 & & & 4 & & 2 & 2 \\
Only teacher-correction & 2.13 & 1.22 & 2.20 & 1.34 & 4 & & & 4 & & \\
Immediate error correction & 2.23 & 1.10 & 1.96 & 1.15 & 4 & & & 4 & & \\
Direct feedback & 3.50 & 1.13 & 3.46 & 1.30 & 4 & & & 4 & & \\
Explicit correction & 4.00 & .87 & 3.93 & .78 & 4 & & & 4 & & \\
\hline
\end{tabular}

Table 5 shows that Arab and non-Arab EFL teachers have similarity of perceptions about error correction in grammar teaching. Both groups of teachers not only tolerate their students' grammatical errors but also believe in peer correction, provision of direct feedback and explicit correction; however, they do not believe in only teachercorrection and immediate feedback. Moreover, there are no differences in their classroom practices.

However, teachers' classroom practices are not completely consistent with their beliefs. The result shows that only two non-Arab teachers tolerate students' errors, while the other two non-Arab and all the four Arab teachers do not tolerate their students' grammatical errors and consider students' grammatical errors an indicator of poor language learning which has to be avoided at any cost. They probably believe that students' grammatical errors will be fossilized if they are not corrected. It was observed that the two non-Arab teachers tolerated only oral errors committed by students; however, they did not tolerate their students' written errors. It was observed that there was no peer correction, a collaborative approach, but only teacher-correction. Moreover, teachers corrected students' oral and written errors immediately, and no one followed wait-time technique. It implies that teachers do believe that delayed error correction leads to better communication, as it does not interrupt the flow of communication. However, they also understand that immediate correction is instrumental on the grounds that it avoids fossilization of errors though it may interrupt the flow of communication. Table 5 further displays that teachers' practice and belief regarding direct error correction are congruent with one another. This way of dealing with students' oral and written grammatical errors can be attributed to the importance given to accuracy instead of fluency by teachers. Table 5 also illustrates that there is consistency in teachers' beliefs and practices regarding explicit correction. This behaviour indicates that either the teachers do not consider the other kinds of error correction beneficial for their students, and purposefully avoid them, or they lack varying strategies to address their students' errors.

The results of the study regarding respondent teachers' intolerant attitude towards errors and only-teacher correction are consistent with that of Jalalifarahani and Azizi's (2012) findings, who reported that only teachers provided feedback which was effective as it guaranteed quality. Moreover, the finding of the study about immediate correction is inconsistent with the finding of Ahmad and Radzuan's (2015), where teachers did not immediately correct students' grammatical errors, as it may have adverse effect on the self-image and motivation of the students. The probable reason for the contradiction in respondent teachers' beliefs and practices about immediate correction may be the current examination system which concentrates on evaluating students' understanding of the grammatical rules. The finding of the study regarding explicit correction is consistent with the finding by $\mathrm{Ng}$ and Farrell (2003), where teachers used explicit correction rather than elicitation as the latter demands more time which was not practical according to teachers.

Table 6. Comparative analysis of male and female EFL teachers' beliefs and practices in grammar teaching approaches

\begin{tabular}{lccccccccccc}
\hline & \multicolumn{4}{c}{ Questionnaire } & \multicolumn{4}{c}{ Classroom Observartion } \\
\cline { 2 - 11 } & \multicolumn{3}{c}{ Male } & \multicolumn{2}{c}{ Female } & \multicolumn{3}{c}{ Male } & \multicolumn{3}{c}{ Female } \\
\cline { 2 - 11 } & $\mathrm{M}$ & SD & M & SD & F & O & N & F & O & $\mathrm{N}$ \\
\hline PPP Approach & 2.16 & .79 & 2.13 & .97 & 1 & 3 & & 1 & 3 & \\
Task-based teaching & 4.20 & .76 & 4.20 & .66 & & & 4 & & & 4
\end{tabular}




\begin{tabular}{llllllllll} 
Rule-driven Approach & 2.26 & .78 & 2.30 & .91 & 4 & & 4 & & \\
Rule-discovery Approach & 4.20 & .55 & 4.13 & .57 & & 4 & & \\
Focus on Forms & 2.33 & .95 & 2.36 & 1.32 & 4 & & & 4 & \\
Focus on Function & 4.33 & .60 & 4.10 & .48 & & 4 & & 4 \\
Intensive grammar teaching & 3.70 & 1.05 & 3.60 & 1.24 & & 4 & & 4 \\
Use of teaching aids & 4.30 & .59 & 4.10 & .75 & 4 & & & 4 \\
\hline
\end{tabular}

The results in Table 6 reveal that non-native male and female EFL teachers hold the same perceptions about grammar teaching approaches. Overwhelming majority of the respondent teachers believe in following innovative approaches and overrule following traditional approaches. Moreover, majority of the teachers believe in intensive grammar teaching and the use of teaching aids. Furthermore, Table 6 also displays that male and female EFL teachers have similarity in classroom practices. However, it was observed that one male and one female teacher followed all the three stages of PPP approach, while three male and three female teachers followed only presentation and practice stages of the approach, and did not proceed to the production stage, so that students may practice the given grammatical structure independently.

Comparing respondent teachers' grammar teaching beliefs and practices, as shown in Table 6, there is almost complete mismatch. Non-native male and female EFL teachers do not practice what they believe in. The classrooms of these teachers are more traditional than modern in teaching grammar to university students. Regarding the use of teaching aids in grammar teaching, there is similarity in their belief and practice; however, teachers used teaching aids only occasionally. Teachers did not use authentic materials in their teaching.

The findings of the study about traditional and innovative grammar teaching approaches are consistent with the findings by Hos and Kekec (2014), whose study revealed that teachers mainly taught English grammar through traditional approaches as opposed to the their statements that they use innovative techniques in their grammar lessons, which shows mismatch between their beliefs and practices. They reported that participants expressed that grammar should be taught contextually rather than in a mechanical way; however, observations showed that their lessons were mostly based on mechanical presentation of the grammar with a focus on drills and exercises. Similarly, the result of the study regarding focus on forms and focus on meaning instruction is consistent with the results reported by Alghanmi and Shukri (2016), who reported that overwhelming majority of the teachers followed focus on forms approach as opposed to their belief of focus on meaning approach. Moreover, the finding of the study about rule-driven and rule-discovery approach is similar to the finding by Ezzi (2012), who reported that majority of the participants taught grammar only deductively as opposed to their belief of teaching grammar lessons inductively. Furthermore, the finding of the study about the use of teaching aids is inconsistent with the finding by Al-Azri and Al-Rashdi (2014), who consider that authentic materials give students a taste of the real language as it is used beyond classroom environment.

Table 7. Comparative analysis of male and female EFL teachers' beliefs and practices in error correction in grammar teaching

\begin{tabular}{lcccccccccc}
\hline & \multicolumn{4}{c}{ Questionnaire } & \multicolumn{4}{c}{ Classroom Observartion } \\
\cline { 2 - 12 } & \multicolumn{3}{c}{ Male } & \multicolumn{1}{c}{ Female } & \multicolumn{3}{c}{ Male } & \multicolumn{3}{c}{ Female } \\
\cline { 2 - 12 } & $\mathrm{M}$ & SD & M & SD & F & O & N & F & O & $\mathrm{N}$ \\
\hline Tolerate students' errors & 3.90 & .99 & 2.90 & 1.47 & & 1 & 3 & & 1 & 3 \\
Only teacher-correction & 2.10 & 1.32 & 2.23 & 1.25 & 4 & & & 4 & & \\
Immediate error correction & 2.16 & 1.17 & 2.03 & 1.09 & 4 & & & 4 & & \\
Direct feedback & 3.46 & 1.30 & 3.50 & 1.13 & 4 & & & 4 & & \\
Explicit correction & 3.96 & .71 & 3.96 & .92 & 4 & & & 4 & & \\
\hline
\end{tabular}

The results in Table 7 illustrate that there is no difference in the perceptions of male and female EFL teachers about error correction in grammar teaching. Majority of both groups of genders believe in tolerant attitude towards students' errors and provide explicit feedback directly. Moreover, they do not believe in only-teacher correction 
and immediate feedback. Furthermore, the results reveal that more male teachers than female teachers believe in tolerant attitude towards students' grammatical errors. Table 7 also shows that there is similarity in teachers' practices as well.

Comparing male and female EFL teachers' beliefs and practices regarding error correction, there is inconsistency in their beliefs and practices in tolerant attitude towards errors, only-teacher correction and immediate provision of errors. However, teachers' beliefs match their practices in direct feedback and explicit correction. Table 7 also displays that only one male and one female teacher occasionally tolerate students grammatical errors, while majority of the teachers do not tolerate. Observations revealed that these two teachers tolerated only oral errors and did not tolerate students' written errors. The findings indicate that gender has nothing to do with teacher cognition in grammar teaching. This may be interpreted in terms of a common teaching and learning environment.

The finding of the study about teachers' intolerant behaviour is inconsistent with the finding by Alghanmi and Shukri (2016), who reported that majority of the teachers believe in error correction and corrected students' grammatical errors. However, this finding is consistent with the finding by Assalahi (2013), who reported that respondent teachers considered students' errors as indicators of bad linguistic behaviours. Also, the result of the study about teacher-correction is in harmony with Assalahi (2013), where teachers believed that the job of correction can be done only by language teachers, as only they can guarantee quality. Moreover, the finding of the study about immediate correction is supported by Hos and Kekec (2014) who reported that majority of the teachers corrected students' errors immediately in order to prevent the formation of bad habits, and if errors are not corrected immediately then they can be fossilized.

\section{Conclusion and Recommendations}

Given the findings of the study, this study reveals that beliefs of non-native EFL teachers across mother tongue and gender are not aligned with their actual classroom practices in teaching grammar resulting in weak teacher cognition and hence, low proficiency level of their students, as beliefs and practices of teachers are not mutually informing. Beliefs and practices of these teachers do not overlap, seem to be mostly poles apart, and positioned on two extremes of a continuum. Such a weak interplay leads to weak teacher cognition, which is one of the main factors considerably responsible for the present teaching standard of English language grammar in the Saudi Arabian context. It is so because a teacher's weak cognition acts as a weak filter and a strong cognition acts as a strong filter through which instructional judgments are made.

Moreover, the interplay between teachers' beliefs and practices directly influences students' proficiency level in the target language. Strong interplay between teachers' beliefs and practices manifests into strong teacher cognition, leading to students' high proficiency level; while weak interplay reflects into weak teacher cognition, resulting in low proficiency level of students. Borg (2009) states that strong interplay between teachers' beliefs and practices are very crucial, as teachers' mental lives play a key role in their instructional choices. The results of the study are in line with the findings reported earlier, for example, Hos and Kekec (2014), and Phipps and Borg (2009) reported that beliefs and practices of grammar teachers were not aligned. However, the findings of the study are inconsistent with the findings of Alghanmi and Shukri (2016), who reported that teachers' beliefs are mostly reflected in their classroom practices.

Furthermore, this study finds out that, irrespective of differences in mother tongue and gender, non-native EFL teachers in the Saudi Arabian context followed the same rigid traditional approaches in grammar teaching. They opt or are forced to opt such traditional approaches. Theoretically they are convinced of meaning-focused communicative approaches; however, practically the scenario presents a bleak picture. This kind of behavior culminates into weak teacher cognition, and hence students' proficiency level remains the victim.

This study is conducted with certain limitations. Teacher cognition, according to Borg (2003), comprises knowledge, beliefs and practices of teachers. However, it was not within the scope of this study to investigate teachers' knowledge of grammar. The study deals with EFL teachers' beliefs and their classroom practices regarding grammar teaching. Moreover, the study investigated EFL teacher cognition in grammar teaching from teachers' perspectives only. Students' perspectives about their teachers' practices in grammar teaching might have enriched the results more. Also, further studies need to be conducted by the addition of semi-structured interviews to illuminate us the factors responsible for weak interplay between teachers' beliefs and practices in grammar teaching.

In line with the findings of this study, some implications are suggested for improved teacher cognition and thus, better grammar teaching and learning in the Saudi Arabian EFL context. Teachers need to make self-observations and reflect on their practices in order to raise awareness about their cognition in grammar teaching. Teachers need to be regularly provided with feedback on their teaching behaviour by the quality 
maintaining cell in educational institutions. It is only after teachers become aware of their actual classroom practices; then they can begin to address how to improve their classroom behaviour. Moreover, continuous professional development is essential and teachers need on-going training workshops to keep their knowledge abreast of the new techniques for teaching grammar. Furthermore, investigating the interplay between teachers' beliefs and practices can assist teacher trainers to provide effective in-service training.

The current study makes a contribution to the field of teacher cognition as its methodology offers an in-depth understanding of non-native EFL teachers' beliefs, their actual classroom practices and the interplay between their beliefs and practices that shape their cognition in grammar teaching.

\section{References}

Ahmad, I., \& Radzuan, N. R. M. (2015). EFL teacher perceptions of error correction in grammar teaching: A case study. International Journal of Language Education and Applied Linguistics (IJLEAL), 3, 37-50.

Al-Azri, R. H., \& Al-Rashdi, M. H. (2014). The Effect of Using Authentic Materials in Teaching. International Journal of Scientific \& Technology Research, 3(10), 249-254.

Alghanmi, B., \& Shukri, N. (2016). The relationship between teachers' beliefs of grammar instruction and classroom practices in the Saudi context. English Language Teaching, 9(7), 70-86. https://doi.org/10.5539/ elt.v9n7p70

Aljohani, M. A. S. (2012). Grammar Beliefs of in-Service Teachers. British Journal of Arts and Social Sciences, $11(1), 96-108$.

Al-Mekhlafi, A. M., \& Nagaratnam, R. P. (2012). Difficulties in teaching and learning grammar in an EFL context. International Journal of Instruction, 4(2), 69-92.

Al-Naeem, L. (2007). Teaching Grammar via the Inductive Approach: A Quantitative-Qualitative Study Conducted in an EFL Setting (Unpublished master's thesis). Imam Muhammad Ibn Saud Islamic University, Riyadh, Saudi Arabia.

Alnaqeeb, A. M. A. (2012). A study of Yemeni English teachers' classroom practices and approaches with special reference to secondary schools in Laboos (Unpublished doctoral dissertation). University of Pune, India.

Al-Seghayer, K. (2011). English Teaching in Saudi Arabia: Status, Issues, and Challenges. Riyadh: Hala Print Co.

Assalahi, H. M. (2013). Why is the grammar-translation method still alive in the Arab world? Teachers' beliefs and its implications for EFL teacher education. Theory and Practice in Language Studies, 3(4), 589-599. https://doi.org/10.4304/tpls.3.4.589-599

Batstone, R., \& Ellis, R. (2009). Principled grammar teaching. System, 37, 194-204. https://doi.org/10.1016/j. system.2008.09.006

Borg, S. (1998). Teachers' pedagogical systems and grammar teaching: A qualitative study. TESOL Quarterly, 32(1), 9-38. https://doi.org/10.2307/3587900

Borg, S. (1999). Teachers' theories in grammar teaching. ELT Journal, 53(3), 157-167. https://doi.org/10.1093 /eltj/53.3.157

Borg, S. (2009). Introducing language teacher cognition. Retrieved from http://www.education/leeds/ac.uk/ research/files/145.pdf

Borg, S. (2003). Teacher cognition in grammar teaching: A literature review. Language Awareness, 12(2), 96-108. https://doi.org/10.1080/09658410308667069

Borg, S. (2013). Teacher research in language teaching: A critical analysis. Cambridge, UK: Cambridge University Press.

Canh, L. V. (2011). Form-focused instruction: A case study of Vietnamese teachers' beliefs and practices (Unpublished doctoral dissertation). The University of Waikato, New Zealand).

Chowdhury, M. H. (2014). Teaching Grammar in the English Language Classroom in Saudi Universities. Express, an International Journal of Multi-Disciplinary Research, 1(1), 1-9.

Cooper, H., \& Hedges, L. V. (1994). The Handbook of Research Synthesis. New York: Russel Sage Foundation.

Creswell, J. W. (2012). Educational research: planning, conducting, and evaluating quantitative and qualitative 
research (4th ed.). Boston, MA: Pearson.

Denzin, N. K. (2012). Triangulation 2.0. Journal of Mixed Methods Research, 6(2), 80-88. https://doi.org/10.11 $77 / 1558689812437186$

Dörnyei, Z. (2007). Research Methods in Applied Linguistics: Quantitative, Qualitative and Mixed Methodologies. Oxford: Oxford University Press.

Ellis, R. (2006). Current Issues in the Teaching of Grammar: An SLA Perspective. TESOL Quarterly, 40(1), 83-107. https://doi.org/10.2307/40264512

Ezzi, N. A. A. (2012). Yemeni Teachers' Beliefs of Grammar Teaching and Classroom Practices. English Language Teaching, 5(8), 170-184.

Fraenkel, J. R., \& Wallen, N. E. (2003). How to design and evaluate research in education. New York: McGraw-Hill.

Gabillon, Z. (2013). A Synopsis of L2 Teacher Belief Research. Belgrade International Conference on Education 2013, Belgrade, Serbia. Retrieved from https://halshs.archivesouvertes.fr/file/index/docid/940593/filename/1._Z.Gabillon_A_Synopsis_of_L2_Tea cher_Belief_Research_BICE_Conference.pdf

Gilje, T. M. (2011). Teacher cognition and the teaching of EFL reading at the Norwegian intermediate level (Unpublished master's thesis). University of Stavanger, Norway.

Grami, M. A. G. (2010). The Effects of Integrating Peer Feedback into University-level ESL Writing Curriculum: A Comparative Study in a Saudi Context (Unpublished doctoral dissertation). Newcastle University, Newcastle upon Tyrne, United Kingdom.

Griffee, D. T. (2012). An Introduction to Second Language Research Methods: Design and Data. Berkeley, CA: TESL-EJ Publications.

Hamid, M. R. (2017). Data Collection and Analysis. University Malaysia Pahang: Kuantan, Malaysia.

Hitchcock, G., \& Hughes, D. (1995). Research and the teacher (2nd ed.). London: Routledge.

Hos, R., \& Kekec, M. (2014). The mismatch between non-native English as a foreign Language (EFL) teachers' grammar beliefs and classroom practices. Journal of Language Teaching and Research, 5(1), 80-87. https://doi.org/10.4304/jltr.5.1.80-87

Jalalifarahani, M., \& Azizi, H. (2012). The efficacy of peer vs. teacher response in enhancing grammatical accuracy \& general writing quality of advanced vs. elementary proficiency EFL learners. 2012 International Conference on Language, Medias and Culture 33, 88-92. Retrieved from http://www.ipedr.com/vol33/018-ICLMC2012-L10005.pdf

Javid, C. Z., Farooq, U., \& Gulzar, M. A. (2012). Saudi English-major undergraduates and English Teachers' perceptions regarding effective ELT in the KSA: A Comparative Study. European Journal of Scientific Research, 85(1), 55-70.

Kalsoom, T., \& Akhtar, M. (2013).Teaching Grammar: Relationship between Teachers' Beliefs and Practices. Global Journal of Human Social Science, 13(12), 54-61.

Khan, I. A. (2011). The Teacher of English: Pedagogic Relevance in Saudi Arabia. English Language Teaching, 4(2), 112-120. https://doi.org/10.5539/elt.v4n2p112

Mohamed, N. (2006). An Exploratory Study of the Interplay between Teachers'Beliefs, Instructional Practices \& Professional Development (Unpublished doctoral dissertation). The University of Auckland, New Zealand.

Ng, E. K. J., \& Farrell, T. S. C. (2003). Do teachers' beliefs of grammar teaching match their classroom practices? A Singapore Case Study. In D. Deterding., Brown A., \& Low E L (Eds.), English in Singapore: Research on Grammar (pp. 128-137). Singapore: McGraw Hill.

Nishimuro, M., \& Borg, S. (2013). Teacher Cognition and Grammar Teaching in a Japanese High School. JALT Journal, 35(1), 29-50.

Pajares, M. F. (1992). Teachers' beliefs and educational research: Cleaning up a messy construct. Review of Educational Research, 62(3), 307-332. https://doi.org/10.3102/00346543062003307

Phipps, S., \& Borg, S. (2009). Exploring tensions between teachers' grammar teaching beliefs and practices. System, 37, 380-390. https://doi.org/10.1016/j.system.2009.03.002 
Sato, K., \& Kleinsasser, R.C. (2004). Beliefs, practices, and interactions of teachers in a Japanese high school English department. Teaching \& Teacher Education, 20, 797-816. https://doi.org/10.1016/j.tate.2004. 09.004

Seliger, H. W., \& Shohamy, E. (1989). Second Language Research Methods. Oxford: Oxford University Press.

Shiu, L. J. (2011). EFL learners' perceptions of grammatical difficulty in relation to second language proficiency, performance, and knowledge (Unpublished doctoral dissertation). University of Toronto, Canada.

Utami, D. N. (2016).The EFL teachers' beliefs and their teaching practices. OKARA Journal of Languages and Literature, 2(10), 135-144. https://doi.org/10.19105/ojbs.v10i2.974

Uysal, H. H., \& Bardakci, M. (2014). Teacher beliefs and practices of grammar teaching: focusing on meaning, form, or forms? South African Journal of Education, 34(1), 1-16. https://doi.org/10.15700/201412120943

Zohrabi, M. (2013). Mixed method research: Instruments, validity, reliability and reporting findings. Theory and Practice in Language Studies, 3(2), 254-162. https://doi.org/10.4304/tpls.3.2.254-262

\section{Copyrights}

Copyright for this article is retained by the author(s), with first publication rights granted to the journal.

This is an open-access article distributed under the terms and conditions of the Creative Commons Attribution license (http://creativecommons.org/licenses/by/4.0/). 